\title{
Informe de las autoridades de las provincias coloniales que formaban el actual territorio de Panamá sobre el poblamiento, rendido con base en real cédula de 24 de abril de 1801
}

ACCESO 6 ABIERTO

Para citaciones: Orozco, K., y Romero, Y (2020). Informe de las autoridades de las provincias coloniales que formaban el actual territorio de Panamá sobre el poblamiento, rendido con base en real cédula de 24 de abril de 1801. El taller de la Historia, 12(2), 502-530.

Recibido: Diciembre de 2020

Aprobado: Diciembre de 2020

Editor: Sergio Paolo Solano. Universidad de Cartagena-Colombia.
Copyright: @ 2020 . Orozco, K., y Romero, Y. Este es un artículo de acceso abierto, distribuido bajo los términos de la licencia https://creativecommons.org/licenses/bync-sa/4.0/ la cual permite el uso sin restricciones, distribución y reproducción en cualquier medio, siempre y cuando que el original, el autor y la fuente sean acreditados.

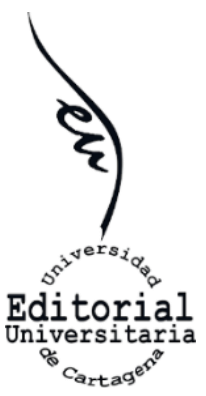

\section{Archivo General de la Nación-Colombia, Sección Colonia, Fondo Historia Civil, Tomo 3, documento 14, folios 845 recto-873 vuelto.}

Karen Victoria Orozco Sarabia ${ }^{1}$, Yorleth Santiago Romero ${ }^{2}$

Universidad de Cartagena, Colombia.

\section{Presentación}

Pese a que durante tres siglos la historia de Panamá estuvo ligada a la de Colombia, el conocimiento que tenemos los colombianos de la primera es nulo. Más allá de las múltiples razones de corto y largo plazo que explican la separación de Panamá, los vínculos entre el Caribe neogranadino y el Istmo fueron intensos a lo largo del periodo colonial. Y continuaron durante el último tercio del siglo XIX cuando se desarrollaban los trabajos de construcción del canal interoceánico. Por eso sigue siendo un error seguir estudiando el Caribe neogranadino y el del siglo XIX sin incluir a las distintas provincias que formaban a lo que hoy es la actual república de Panamá.

No solo se trata de que las rutas de las flotas de galeones tocaran puertos en las ciudades de Cartagena de Indias y de Portobelo, dando origen a ferias comerciales que movilizaban a comerciantes provenientes de las audiencias de Quito y Chile y del virreinato del Perú, activando la vida económica de esos centros urbanos y de sus alrededores ${ }^{3}$. Durante el siglo XVIII Cartagena de Indias, además de ejercer jurisdicción militar y naval sobre el arco territorial comprendido entre la península de la Guajira hasta los límites con los actuales territorios de Panamá y Costa Rica, abastecía a Portobelo de los principales alimentos que demandaba la población. El fallido intento de colonización del Darién en buena parte recayó sobre los habitantes de la provincia de Cartagena, como la provisión de mano de obra y de materias primas para el mantenimiento de las fortificaciones de esta ciudad

\footnotetext{
1 Transcripción y presentación. Egresada en tesis Programa de Historia, Becaria del Laboratorio de Investigación en Estudios Coloniales Universidad de Cartagena.

${ }^{2}$ Transcripción y presentación Egresada en tesis Programa de Historia, Becaria del Laboratorio de Investigación en Estudios Coloniales Universidad de Cartagena

3 Alfredo Castillero, Nueva historia general de Panamá, vol. 1, tomo 2, El orden colonial. Panamá, Comité Nacional del Centenario, 2004; Alfredo Castillero, Cultura alimentaria y globalización. Panamá, siglos XVI a XXI. Panamá: Ed. Novo S A, 2010; Alfredo Castillero, Biografia de una manzana histórica. The meredith's residence. Panamá: Ed. Novo S A, 2015; Alfredo Castillero, Portobelo y el San Lorenzo de Chagres. Una monografía sobre la historia de las fortificaciones de Panamá en los siglos XVII y XVIII. Panamá: Ed. Novo S A, 2016; Alfredo Castillero, Antología histórica. Artículos, ensayos, conferencias. Panamá: Ed. Novo S A, 2018; Alfredo Castillero, Arquitectura, urbanismo y sociedad. Vivienda, calidad de vida y mentalidades en el Panamá colonial. Panamá: Ed. Novo S A, 2019; Fernando Quiles y Juan Marchena Fernández (eds.), Viajes al corazón del mundo. Las ciudades coloniales del Istmo de Panamá. Sevilla: Universidad Pablo de Olavide, 2021.
} 
panameña ${ }^{4}$, la que fue tomada y saqueada por la armada inglesa dirigida por Edward Vernon, hecho del que nunca más pudo recuperarse ${ }^{5}$.

El documento que ofrecemos al público constituye una radiografía oficial de la ocupación del espacio panameño a comienzos del siglo XIX. Esos informes obedecieron a una exigencia establecida por la Corona española, demanda que se acentuó a partir de 1777, bajo la influencia de la mentalidad reformista borbónica interesada en conocer la geografía, los recursos y las comunidades que las poblaban ${ }^{6}$

\section{Bibliografía}

Castillero, Alfredo, Nueva historia general de Panamá, vol. 1, tomo 2, El orden colonial. Panamá, Comité Nacional del Centenario, 2004.

Castillero, Alfredo, Cultura alimentaria y globalización. Panamá, siglos XVI a XXI. Panamá, Ed. Novo S A, 2010.

Castillero, Alfredo, Biografía de una manzana histórica. The meredith's residence. Panamá, Ed. Novo S A, 2015.

Castillero, Alfredo, Portobelo y el San Lorenzo de Chagres. Una monografía sobre la historia de las fortificaciones de Panamá en los siglos XVII y XVIII. Panamá, Ed. Novo S A, 2016.

Castillero, Alfredo, Antología histórica. Artículos, ensayos, conferencias. Panamá, Ed. Novo S A, 2018.

Castillero, Alfredo, Arquitectura, urbanismo y sociedad. Vivienda, calidad de vida y mentalidades en el Panamá colonial. Panamá, Ed. Novo S A, 2019.

"Diario de una expedición reservada a cargo del capitán de fragata Luis Arguedas", en Antonio B. Cuervo (comp.), Colección de Documentos, tomo I. Bogotá: Imp. de Vapor de Zalamea Hnos., 1891, pp. 371-396;

Montoya Juan D., "Una historia fallida: la conquista del Darién a finales del siglo XVIII". Tareas, 143, (2013): 27-47;

Quiles, Fernando y Marchena Fernández, Juan (eds.), Viajes al corazón del mundo. Las ciudades coloniales del Istmo de Panamá. Sevilla, Universidad Pablo de Olavide, 2021.

Solano, Francisco (ed.), Cuestionarios para la formación de las relaciones geográficas de Indias siglos XVI / XIX. Madrid, CSIC, 1988.

Solano, Sergio Paolo, "Trabajadores, jornales, carestía y crisis política en Cartagena de Indias, 1750-1810”. Historia, 51, II, 2018: 549-588.

\footnotetext{
4 "Diario de una expedición reservada a cargo del capitán de fragata Luis Arguedas", en Antonio B. Cuervo (comp.), Colección de Documentos, tomo I. Bogotá: Imp. de Vapor de Zalamea Hnos., 1891, pp. 371-396; Juan D. Montoya, "Una historia fallida: la conquista del Darién a finales del siglo XVIII". Tareas, 143, (2013): 27-47; Sergio Paolo Solano, "Trabajadores, jornales, carestía y crisis política en Cartagena de Indias, 1750-1810". Historia, 51, II, 2018: 549-588.

${ }^{5}$ Fernando Quiles y Juan Marchena Fernández (eds.), Viajes al corazón del mundo. Las ciudades coloniales del Istmo de Panamá. Sevilla: Universidad Pablo de Olavide, 2021.

${ }^{6}$ Francisco Solano (ed.), Cuestionarios para la formación de las relaciones geográficas de Indias siglos XVI / XIX. Madrid, CSIC, 1988.
} 


\title{
Informe de las autoridades de las provincias coloniales que formaban el actual territorio de Panamá sobre el poblamiento, rendido con base en real cédula de 24 de abril de 1801
}

\author{
Archivo General de la Nación-Colombia, Sección Colonia, Fondo Historia \\ Civil, Tomo 3, documento 14, folios 845 recto- 873 vuelto.
}

\section{Oficios}

Acompaño a usted copia de la Real Cedula de veinticuatro de abril de mil ochocientos uno para que, en vista de su contexto, y de lo proveído por los señores de esta Real Audiencia, le dé su debido cumplimiento, avisándome de su recibo $=$ Dios guarde a usted muchos años Santa fe julio diecinueve de mil ochocientos dos $=$

\section{Real Cédula}

Doctor Francisco José de Aguilar= Señor gobernador de Panamá = El Rey regente, y oidores de mi Real Audiencia de la ciudad de Santafé. por Don José María Lozano, y Peralta vecino de esa ciudad se me ha hecho presente, que ese reino, es el mayor, y más precioso de la América, siento hasta ahora un esqueleto de población, por los interminables terrenos, y dispersión de sus habitantes, los cuales en la mayor parte son hombres del monte, [díscolos], e indisciplinados, que a excepción de esa capital, y el puerto de Cartagena, todo lo demás ni se puede llamar población, ni sacar las ventajas de la sociedad; pues la ciudad de [Tunja] esta medio arruinada: Mompox, y Honda son villas, pero informes: Pamplona, y Neiva, ciudades por honor, las de Alta Gracia, Anserma, La Palma. [folio 845r.] Muzo, Tocaima, y otras han llegado a su exterminio: de forma que el resto de aquellas tierras, fértiles, hermosas, y ricas, son pueblos de indios, y parroquias, que, es decir, una iglesia, y una casa del cura en el centro de las campiñas, so-las ,y sin cultivo, lastimándose el corazón al ver que aquellos [fertilísimos] objetos con que ha enriquecido la naturaleza aquel país, sean sus habitadores tan rústicos, y montaraces que la religión esta lastimosamente perdida, y olvidada, pues un cura párroco, y la justicia por celosos y vigilantes que sean, no pueden separados, ni unidos hacer cumplir los preceptos de Dios. Ni de la iglesia porque los feligreses remontados en la [espesura] de los bosques, alejados en enormes distancias, y pobres voluntarios, por la ociosidad de una vida silvestre, hacen vanas todas las diligencias, de un pastor, y de un juez, oyendo misa los más cercanos en los días de precepto, los demás pasados muchos años, habiendo gentes que nunca la han oído, ni tienen idea de los templos, ni de sus sagradas ceremonias viéndose bautizar muchas veces a fuerza del celo parroquial, muchos de ocho, diez, y hasta de doce años, hallándose también tan relajado el precepto pascual, que se ahuyentan a los montes para eludir la obligación. Y proponen para remedio de estos males aumentos del estado de mi Real Erario, el que se recojan [folio $845 \mathrm{v}$ ] y unan a poblado aquellos habitantes conduciéndoseles a ser hombres por la mutua humanidad, y trato que es la vara para el feliz logro 
de tan necesarios establecimientos, expidiéndose las ordenes correspondientes, para que con la posible brevedad, y exactitud se arreglen los poblados, comisionando sujetos de integridad de los que se hallen asalariados por mí para obviar derechos de comisión que podrán serlo los gobernadores en las provincias, los corregidores en los partidos, los oidores en las cercanías de esa ciudad y otros vecinos de inteligencia, y desinterés, para conducir con acierto las más proporcionadas poblaciones, imitando a los vecinos del respectivo territorio a que hagan sus moradas en el terreno de la parroquia, haciéndose garantes de las utilidades que reportaran, y mayormente la de huir de las vejaciones que los particulares les hacen por estar las justicias remotas, no habiéndose propuesto en este pensamiento más objeto que el de la felicidad de ese reino, y las riquezas consideradas que lograra el estado, ofreciendo suministrar las luce que conduzcan al logro de la empresa si se le considera capaz por el conocimiento que asiste de algunas provincias de él. Visto en mi concejo de las indias con lo expuesto por su contaduría general, y mi fiscal, y habiéndose consultado sobre ello en doce de febrero último: he resuelto informéis con justificación [folio 846r] a la mayor brevedad como os lo mando, cuando se os ofrezca, y parezca en el referido asunto fecha en Aranjuez a veinticuatro de abril de mil ochocientos y uno $=$ yo el Rey $=$ por mandado del Rey nuestro señor $=$ Silvestre Collar $=$ Hay tres rubricas $=$

\section{Obedecimiento}

En la Ciudad de Santa fe a veintiuno de abril de mil ochocientos dos. Estando en el Real Acuerdo de Justicia los señores virrey presidente regente, y oidores de la Audiencia, y Cancillería Real de este nuevo Reino de Granada, habiendo visto la Real Cedula antecedente dijeron: que la obedecían, y obedecieron en la forma acostumbrada, y que para su cumplimiento sacándose copia de este original que se archivara se de vista al señor fiscal, y lo rubricaron por ante mí de que certifico $=$ Hay dos rubricas $=$ Doctor Aguilar $=$ Es copia de $\mathrm{su}$ original Santafé Mayo cuatro de mil ochocientos dos = Doctor Francisco José de Aguilar $=$ de oficio $=$ Corregido $=$

\section{Vista fiscal}

Muy poderoso señor $=\mathrm{El}$ fiscal de lo civil dice: que obedecida el antecedente Real Cedula fecha en Aranjuez a veinticuatro de abril del año próximo pasado, que igual se ha comunicado al superior Gobierno donde se tiene pedido lo conveniente para su cumplimiento, es de mandarse guardar, cumplir, y ejecutar en todo lo que previene, y para el efecto de instruir el informe de Tribunal con la debida justificación, oír previamente los de los cabildos [folio $846 v$ ] y curas en la parte que a cada uno corresponde por medio de los gobernadores y corregidores de las provincias, a quienes se servirá vuestra Alteza comunicar las ordenes necesarias, reservando para practicar en su vista las demás diligencias que esta superioridad tenga a bien, y que se 
consideren convenientes $=$ Santafé Mayo siete de mil ochocientos dos $=$ Baya $=$ Autos $=$ Hay una rúbrica $=$

Decreto

Proveyóse por los señores virrey presidente, y oidores de la Audiencia y cancillería Real del Reino en Santafé a diez de mayo de mil ochocientos dos $=$ Doctor Aguilar $=$ vistos como parece al Señor Fiscal $=$ Hay dos rubricas $=$

\section{Auto}

Proveyose por los señores virrey, presidente regente y oidores de la Audiencia y Cancillería Real del reino en Santafé a veintiséis de mayo de mil ochocientos dos $=$ Doctor Aguilar $=$

\section{Notificación}

En Santafé a veintiocho de los mismos. Yo el escribano receptor pase noticia del superior Auto que antecede el Señor Don Manuel Mariano Blaya, Fiscal de su majestad quedo impuesto su señoría rubrica doy fe $=$ Hay una rúbrica $=$ Herrera = Es copia de su original Santafé julio catorce de mil ochocientos y dos años $=$ Doctor Francisco José de Aguilar $=$ de oficio $=$ Hay una rúbrica $=$ corregido $=$ Hay una rúbrica $=$

\section{Decreto}

Panamá y agosto treinta, y uno de mil ochocientos dos $=$ por recibido el testimonio de la Real Cedula que comprende se obedece, cumpla, y ejecute [folio 847r] como en ella se manda, y para que se verifique dese vista al abogado Fiscal $=$ Antonio de Narváez y la Torre $=$ Doctor Don Joaquín Cabrejo $=$ Ciriaco Hipólito Correoso $=$

\section{Notificación}

En Panamá en dicho día, mes, y año hice saber este decreto al Señor Doctor Don Rafael Macías abogado fiscal $=$ Hay una rúbrica $=$ Correoso $=$ Señor gobernador y comandante general $=$

Vista fiscal

El abogado fiscal dice que para cumplir con el informe preceptuado por el superior tribunal de la Real Audiencia del distrito a consecuencia de lo que su majestad ordena en la Real Cedula comprendida en el testimonio antecedente le parece sería necesario pasar una visita general, y exacta de todos los pueblos de esta provincia para instruirse con un practico conocimiento del estado de su población, ocupaciones de sus vecinos, y proporciones que haya para la agricultura e industria, pero supuesto que esta no se verifique, podrá usía mandar a los respectivos cabildos de esta ciudad la de Natá, y villa de 
los Santos, que destinen sujetos de su satisfacción que verifiquen en los pueblos de la respectiva comprensión de cada uno el prolijo, y exacto reconocimiento que queda insinuado; y hecho remitan las diligencias con el correspondiente informe a este gobierno para evacuar el que manda se alteza Panamá, y septiembre trece de mil ochocientos dos = Doctor Macías = Autos $=$ Hay dos rubricas $=$

\section{Decreto}

Proveyó [folio 847v] y rubricó este decreto el señor Don Antonio de Narval y la Torre, Brigadier de Infantería de los reales ejércitos, gobernador, comandante general, subdelegado general de Rentas Reales de este reino con el dictamen del señor Doctor Don Joaquín Cabrejo su teniente asesor general quien también lo rubricó. Panamá septiembre trece de mil ochocientos dos años $=$ Ciriaco Hipólito Correoso $=$

\section{Notificación}

En Panamá en dicho día, mes, y año hice saber este decreto al Doctor Don Rafael Masías abogado fiscal $=$ hay una rúbrica $=$ Correoso $=$

\section{Decreto}

Visto: y considerando, que los cabildos por lo general, están impuestos del estado, en que se hallan, los lugares de su distrito el de la Ciudad de Natá, y el de la Villa de los Santos informen sobre el contenido de esta Real Cedula, para cuyo efecto se expedirá orden, y se les remitirá copia de ella; y si acaso de alguno o de algunos de ellos no tuvieren el conocimiento necesario destinaran sujeto de su satisfacción, que hallándose instruido de lo referido, las ministre las luces necesarias para dicho efecto $=$ Narváez $=$ Doctor Cabrejo = proveyó, y firmo este decreto el señor Don Antonio de Narváez, y la Torre Brigadier de infantería de los Reales Escritos, gobernador, comandante general, subdelegado general de Rentas Reales de este reino con dictamen del señor Doctor Don Joaquín Cabrejo su teniente asesor general quien también [folio 848r] lo firmo Panamá septiembre veintitrés, de mil ochocientos y dos años $=$ Ciriaco Hipólito Correoso $=$

\section{Notificación}

En Panamá en dicho día, mes, y año hice saber este Auto al Doctor Don Rafael Macías abogado fiscal $=$ Hay una rúbrica $=$ Correoso $=$

\section{Nota}

Se sacaron dos copias de la Real Cedula que en testimonio pese de, y se entregaron en la secretaria del señor gobernador, y comandante general para 
que se dirijan a los cabildos de Nata, y Villa de los Santos = Hay una rúbrica $=$

\section{Decreto}

Respecto al atraso que se experimentó en el informe que se ha pedido a los cabildos de Natá, Villa de los Santos recuérdeles por la escribanía de este gobierno con copia de este decreto, y el de veintitrés de septiembre del año próximo pasado a fin de que se evacuen, y remitan a este gobierno con la prontitud posible para que no se demore el curso de este expediente $=$ Doctor Cabrejo = proveyó, y firmo este decreto el señor Doctor Don Joaquín Cabrejo, abogado de los Reales Consejos, teniente de gobernador, auditor de guerra, asesor general de gobierno que despacha lo político por enfermedad del señor gobernador y comandante general de este reino, Panamá y enero veintiséis de mil ochocientos y tres años $=$ Ciriaco Hipólito Correoso $=$

\section{Nota}

Se remitieron a los Cabildos de Natá y Villa de los Santos las copias que se previenen en el decreto precedente [folio 848v]

[Decreto]

Panamá fecha. [Ut supra] $=$ Correoso $=$ vuélvase a recordar a los cabildos de la Ciudad de Natá y Villa de los Santos el pronto despacho del informe que se les ha pedido con arreglo a la Real Cedula, y decretos de este expediente remitiéndoseles nuevamente testimonio de ellos, y se espera que lo verifiquen con la prontitud posible con [apercibimiento] que en su defecto será del cargo de los culpados, y negligentes, los resultos, y perjuicios que ocasione la demora, y se tomaron las demás providencias que convengan para que se hagan efectivo su cumplimiento $=$ Urbina $=$ Doctor Cabrejo $=$ proveyó $\mathrm{y}$ firmo este decreto el señor Don Juan de Urbina Brigadier de infantería de los Reales Ejércitos, gobernador, comandante general, y subdelega-do general de Rentas Reales de este reino con dictamen del señor Don Joaquín Cabrejo su teniente asesor general quien también la firmo. Panamá, y agosto veintidós de mil ochocientos, y cuatro años $=$ Ciriaco Hipólito Correoso $=$

Nota

En Panamá en veintitrés de dicho mes, y año se sacaron las dos copias que se previenen en el decreto presente, y pusieron con carta al cabildo de Natá, y Villa de los Santos en la oficina de correo para su conducción a dichos destinos $=$ Correoso $=$

\section{Real Provisión}

Don Carlos por la gracia a Dios, Rey de Castilla, de León de Aragón, de la[s] dos silíceas de Jerusalén, de Navarra de Granada, de Toledo, de Valencia, de 
[folio 849r] Galicia, de Mallorca, de Sevilla, de Cerdeña, de Córdoba, de Córcega, de Murcia, de Jaén, de los Algarbe, de Gibraltar, de las islas de canaria, de las indias orientales y occidentales, islas, y tierra firme del mar océano, Archiduque de Austria; Duque de Borgoña, de Brabante, y de Milán; Conde de [Hamburgo], de Flandes, Figol[s], y Barcelona; señor de Vizcaya, $\mathrm{y}$ de Molina [ilegible] = por cuantos por mi virrey ,presidente regente, $\mathrm{y}$ oidores de mi Audiencia, y Cancillería Real de este Nuevo Reino de Granada se recibió una mi Real Cedula expedida en Aranjuez a veinticuatro de abril de mil ochocientos, y uno, para que este tribunal informase sobre lo representado por Don José María Peralta a cerca de las poblaciones de este reino, la que obedecida se me mando a circular, y circulo a las cabezas de provincias del distrito de esta capital a efecto de oír previamente los de los cabildos, y curas en la parte que a cada uno corresponde: y no habiendo dándose el debido cumplimiento por ese gobierno, sin embargo, se haber sido repetidamente recordado por órdenes comunicadas, prevenidas por mi auto de doce de mayo de ochocientos tres; se dio vista a mi fiscal de lo civil, y con lo que expuso, se proveyó por mis ministros en veintiséis de junio de ultimo el auto siguiente. Visto: esperen se los demás informes, que enuncia el señor fiscal en su antecedente vista, y resultando [folio $849 \mathrm{v}$ ] de la nota puesta por escribana el dilatado tiempo de más de un año que ha ocurrido desde la última providencia en que se previno a los gobernadores, y corregidores, que faltaban por dar cumplimiento se les repetirá la correspondiente Real Provisión para que en el perentorio termino de un mes lo ejecuten bajo apercibimiento en caso de no verificarlo, a las más serias demostraciones por tanto, fue acordado por los referidos mis ministros, el que se debía librar esta mi Real Carta lo que he tenido a bien, y por ella os ordeno y mando a vos mi gobernador de Panamá que luego, que la recibáis veáis su contenido, y en su cumplimiento haréis lo tenga mi auto inserto, sin hacer cosa en contrario pena de doscientos pesos, para mi cámara, y fisco. Dado en Santafé a veintiuno de agosto de mil ochocientos cuatro $=$ yo el Doctor Don Francisco José de Aguilar, y Contreras abogado, y secretario de cámara, y acuerdo de la Audiencia y Cancillería Real de este Nuevo Reino la hice escribir por su mandado con acuerdo de su virrey regente, y oidores $=$ Hay una rúbrica $=$ Antonio Amar $=$ Juan Hernández de Alba = Romualdo Antonio de Inclán = Lugar del real sello $=$ Registrada $=$ Don Doctor Juan Antonio Guzmán $=$ por el canciller $=$ Doctor Juan Antonio Guzmán

\section{Decreto}

Panamá octubre nueve de mil ochocientos cuatro $=$ pase al señor asesor general la Real Provisión que antecede $=$ Urbina $=$

\section{Otro}

Panamá octubre once [folio 850r] de mil ochocientos cuatro = Agregándose a los antecedentes de la materia, y corra vista con el abogado fiscal = Hay dos 
rubricas $=$ Ciriaco Hipólito Correoso $=$ Hay dos rubricas $=$ Ciriaco Hipólito Correoso $=$

\section{Notificación}

En Panamá en dicho día, mes, y año hice saber este decreto a Don Rafael Masías abogado fiscal $=$ Hay una rúbrica $=$ Correoso $=$ Señor gobernador $y$ comandante general $=$

\section{Vista fiscal}

El abogado fiscal dice: que la extraordinaria, y punible demora que han tenido los cabildos de la Ciudad de Natá y Villa de los Santos en evacuar los respectivos informes que se les mandaron dar en providencia de veintitrés de septiembre de mil ochocientos dos, sin embargo, de los recuerdos que se les han hecho oportunamente por otras de veintiséis de enero de ochocientos tres, y veintidós de agosto último. Ha dado motivo a que se dirija a este gobierno el antecedente real provisión conminándolo con responsabilidad si dentro del término de un mes no cumple con remitir el informe que se le tenía pedido, y para el que se solicitaron los de los dos cabildos referidos. En esta virtud, y aun que el fiscal concibe que es corto el terreno señalado para que dichos cabildos ejecuten lo mandado, y que a su consecuencia se pueda hacer por usía el prevenido informe, pero siempre es preciso agitar el cumplimiento de lo mandado, y para ello lee parece sería conveniente se expida la competente orden al alcalde mayor de dicha Ciudad de Natá, y su partida a fin que haga lo que los [folio 850v.] mencionados cabildos evacuen con la mayor brevedad sus informes respectivos obligándolos a ello con pena pecuniarias, y otras proporcionadas a su culpable omisión, y negligencia, y que por su conducto las remitan a este gobierno sin pérdida de tiempo bajo de responsabilidad para que así pueda usía dirigir el suyo a la Real Audiencia lo más pronto que se pueda con remisión de este expediente o su testimonio, por el que conozca su alteza no haber habido omisión en este gobierno en el exacto cumplimiento de sus superiores mandatos. Panamá, y octubre trece de mil ochocientos cuatro $=$ Doctor Macías $=$ otrosí dice el fiscal que en este instante se ha pasado el informe que ha dirigido al cabildo de Natá con fecha veinte de septiembre próximo pasado, y así debe entenderse su anterior pedimento solo por lo respectivo al cabildo de la villa, y también pide se mande informar al de esta ciudad por lo tocante a los pueblos de su comprensión. Panamá fecha utsupra $=$ Doctor Masías $=$ señor gobernador, $\mathrm{y}$ comandante general $=$

\section{Informe}

El cabildo, justicia, y regimiento de la Ciudad de Natá en cumplimiento del auto de usía en que manda informe según lo dispuesto por el soberano en su Real Cedula hecha en Aranjuez a veinticuatro de abril de mil ochocientos uno en vista del informe que dio Don José Lozano, y Peralta, vecino de la Ciudad de Santa Fe de Bogotá, dice que son tan ciertas, y reales las razones que el 
dicho expone a su majestad que parece tenia [folio $851 r$ ] presente lo que para en esta provincia o lo miraba por medio de algún microscopio, y con esto parece quedaba satisfecho el informe que manda usía de este cabildo sobre la particular, pero cumpliendo con nuestro cargo hacemos a usía presente para que se sirva ponerlo en noticia del soberano la decadencia en que se halla está ciudad, y toda su jurisdicción, y que por este medio su soberana piedad, de los más benignos arbitrios restablecimiento, $\mathrm{y}$ antiguo esplendor $=\mathrm{La}$ Ciudad de Nata fue fundada el año de mil quinientos diecisiete por el licenciado Gaspar Espinoza con el título entonces de Villa y habiendo sido destruida, y quemada por los indios se volvió a reedificar por el año de mil quinientos veintidós por Pedro Darías Dávila con el título de Ciudad que lo concedió la majestad del señor Don Carlos V emperador de Alemania, y primer rey de este nuestro reino; en España haciéndole muchas gracias, y dones cuya memoria quedara inmortal en los venideros siglos. Acompañase entonces de muchas personas ilustres, y nobles, de que le redundo el glorioso [epicentro] de Natá de los caballeros: pero hoy se halla tan abatida, y constituida en tan deplorable estado que apenas merece el nombre de aldea siendo la causa el ningún comercio que tiene ni la aplicación de sus gentes a la agricultura pues, aunque consta su padrón de tres mil trecientos cincuenta, y cinco personas de varias castas, y que los de ellos dominan labradores que pudieron hacerla ventajosa, es tan al contrario que los más viven [folio 851v] esparcidos por los campos dispersos sin sociedad ni cultivo de gentes, y con el vago [epicentro] de labradores pues todas sus labranzas se componen a la siembra de un cuartillo, o un almud de maíz que consumen brevemente en el brebaje de chichas de que nacen varias [embriagueces] con perjuicio de sus propias vidas, y escándalo de la República, siendo está una de las causas principales para verse esta ciudad siempre escasa de alimentos pues entregados sus vecinos al ocio, no cuidan de emplearse en otras obras d manufacturas, y de cultivos sin que les estimule el abatimiento, y pobreza en que se ven constituidos, y por esta razón resultan varios robos que experimentan los hacendados en sus haciendas de ganado $=$ Nace también de esta vida licenciosa, y holgazana que tienen estas gentes del campo, otro perjuicio peor de la República, al bien de la religión, y al de sus propias almas cuales de que carecen de la doctrina cristiana, y conocimiento de las verdades católicas, pues aunque se cura ha hecho, y está haciendo las más eficaces diligencias a reducirlos a que siquiera los pequeños concurriesen, aunque fuese los días domingo o rezar la doctrina cristiana pasando al efecto oficios al alcalde mayor, y este a los ordinarios, y hecho estas cuanto fue posible de su parte no se ha podido lograr en fin de tan santa obra, pues aunque los primeros días concurrieron, se fueron después retirando a sus montes, faltos de obediencia, $\mathrm{y}$ respeto $=$ Resulta también de esta habitación en los campos [folio 852r] que muchos viven en una vida incestuosa, y de tan horrendos delitos que se avergüenza la pluma al ponerlos sin que pueda la justicia remediarlos pues, o no llegan a su noticia, y cuando llegan, y quieren poner remedio no lo consiguen, por carecer de armas con que se puedan auxiliar las justicias pues aunque se hallan alistadas algunas milicias no tienen más que unos fusiles de palo contrahechos con que hacen el ejercicio, con lo cual se hacen más 
insolentes, y cuando llevados del celo de la justicia o en enormidad de los delitos, arman algunos paisanos, y milicianos con armas blancas para en castigo de sus insolencias, con la facilidad, y conocimiento que tienen de sus montes se escapan remontándose más a las montañas que llaman de Petaquilla, y Veragua, o pasándose de unos, a otros lugares en los cuales ni la justicia sabe cuándo vienen, ni cuando se van, y por consiguiente para cumplir con el precepto anual de confesar, y comulgar como manda nuestra santa madre iglesia es necesario que el cura ande averiguando por los sitios los que no han cumplido valiéndose de las Justicias Reales para para que los traigan ha dicho cumplimiento dejándoles a veces morir sin confesión, y dándoles sepultura en los montes $=$ Esta ciudad, aunque en sus principios fue de grande extensión, y hermosamente poblada pues consta en su fundación la diversidad de calles de que se componía, apenas hay hoy noticia de ellas, por haberse ido sucesivamente arruinando sin que sus habitantes, cuiden de su reformación, pues el edificio [folio 852v] que se llega a caer jamás se recupera, siendo la causa de vivir toda la más de la gente en los montes y sitios en donde sujetos a una vida miserable lo pasan en unas casas pajizas, metidas entre matas que le sirve de abrigo a sus vicios, incestos, y robo. Y aun que varias veces se ha mandado por el alcalde mayor la reedificación de casas, aun los sujetos hacendados, y de comodidad, con varios efugios han hecho ilusorias sus providencias, por lo que debía en día camina más a su exterminio, y si la mano poderosa del soberano, no lo remedia quedara sola está ciudad reducida a su iglesia, parroquial convento, hospital capilla de la soledad, y casa del cura, y destruida una ciudad que mereció la atención del soberano = todos estos males parecen a este ilustre cabildo puede remediarse informando usía a nuestro soberano, para que por su real orden se manden extinguir, y quemar todas las habitaciones de las gentes que había en los campos a excepción de aquellos hacendados que reconozca este cabildo, ser útil al bien común, aunque debe si, obligar les a que tenga su casa morada en la ciudad donde deben habitar hasta aquel tiempo en que sea preciso ocurrir al cuidado de sus haciendas, dando para ello al soberano sus estrechas órdenes para que todos los jueces unánimes [celen] sus campos, y hagan lo mismo extinción en ellos, porque de lo contrario hostilizados solo por una parte se refugiaron a los montes de los vecinos que hay en su contorno [folio 853r] según el afecto que tiene a la habitación del monte por la vida holgazana que llevamos referida = por el año pasado de mil ochocientos dos en el mes de diciembre; en obedecimiento de esta misma Real Cedula paso este ilustre cabildo al señor antecesor de usía otro igual informe $=$ En cuanto este cabildo puede informar a usía en cumplimiento de lo mandado por la citada Real Cedula: Natá, y septiembre veinte de mil ochocientos cuatro $=$ Sebastián José de Robles $=$ José Matías [Yanques] $=$ Antonio Pinzón $=$ José María Gutiérrez $=$ Manuel Paulino de Ocaña $=$ Manuel José Castro verde $=$ Juan Francisco de Añino $=$ 


\section{Decreto}

Panamá octubre once de mil ochocientos cuatro $=$ por recibido, agréguese al expediente a la materia y corra la vista dada al abogado fiscal = Hay dos rubricas $=$ Correoso $=$ señor gobernador, $\mathrm{y}$ comandante general $=$

Vista

El abogado fiscal dice: que se esperen los demás informes que ha pedido en vista de esta fecha para que según su mérito se haga por usía el que previene la Real Audiencia. Panamá, y octubre trece de mil ochocientos cuatro = Doctor Masías =

Auto

Autos, y vistas hágase como pide el abogado fiscal, y en su virtud informe el ilustre ayuntamiento de esta ciudad a la mayor brevedad posible, expídase el orden competente al alcalde mayor de Natá, a fin de que esté a la mira de que cumpla el cabildo de la Villa de los Santos con lo prevenido en este expediente procediendo explicar las penas [folio $853 \mathrm{v}$ ] y conminaciones que juzgue oportunas, en caso de continuar la demora, y se espere de su celo, y actividad el pronto cumplimiento de esta provincia $=$ Urbina $=$ Doctor Cabrejo $=$ Proveyó, y firmo este auto el señor Don Juan Urbina brigadier de infantería de los Reales ejércitos, gobernador, comandante general, y subdelegado general de Rentas Reales de este reino con dictamen del señor Doctor Don Joaquín Cabrejo su teniente asesor general quien también lo firmo. Panamá trece de octubre de mil ochocientos cuatro $=$ Ciriaco Hipólito Correoso $=$

\section{Notificación}

En Panamá en dicho día mes, y año hice saber este decreto al Doctor Don Rafael Masías abogado fiscal $=$ Hay una rúbrica $=$ Correoso $=$

Nota

Se libró el orden que se previene en el auto del frente a la alcaldía mayor de Natá $=$ Hay una rúbrica $=$

\section{Decreto}

Cabildo ordinario de Panamá, y octubre diecinueve de mil ochocientos cuatro = Hágase con la posible brevedad el informe mandado dar por el señor gobernador, $\mathrm{y}$ comandante general $=$ Anzoátegui $=$ Berrera $=$ Jiménez $=$ Ortiz $=$ Icaza $=$ Argote $=$ Barrios $=$ Quesada $=$ Maestro Juan José Calvo $=$ 


\section{Informe}

Escribano mayor de cabildo $=$ Señor gobernador, y comandante general $=$ El cabildo de esta ciudad después de haber visto la Real Cedula de veinticuatro de abril de mil ochocientos uno, y cumpliendo con el informe que usía se sirva pedirle a consecuencia de lo preceptuado por el Superior Tribunal de la Real Audiencia del distrito dice: que los inconvenientes representados a su majestad por Don [folio 854 r] José María Lozano, y Peralta, vecino de la Capital de Santafé en orden a la general decadencia de aquel reino por la cortedad de su población, terrenos incultos, y dispersión de sus habitantes, son los mismos que se experimentan en esta provincia, o istmo, cuyos pueblos aniquilados, y con desiertos van constituyéndose cada día en el más próximo estado de ruina, y de su total exterminio $=$ Es a la verdad [cosa] extraña, que conquistado hace cerca de trescientos años este reino de tierra firme, que habiendo estado en sus primitivos tiempos más poblado y que habiendo sido el cauce de las riquezas del Perú por aquel grandioso comercio, que se hizo por medio de los galeones, en vez de haberse fijado por estos motivos su consistencia, y su prosperidad haya ido progresivamente caminando a su decadencia, a pesar de la aptitud prodigiosa de su sueldo para toda especie de producciones naturales, de la afluencia de sus exquisitos minerales de oro de la inagotable pesquería de perlas, y de su admirable situación geográfica para mantener un comercio de propiedad, y las relaciones más activas de comunicación con todos los [puertos] del globo $=$ Prescinden este cabildo de individualizar a que la reunión de muchas infelices causas que sin duda habrán concurrido para sumergir este país en el abismo de su actual deficiencia e infortunio, pero entre ellas no puede menos que reconocer como la más [impulsiva] e influyente su [di minutísima] población, reducida ya a tal extremo, que en una extensión de más de ciento, [folio $854 \mathrm{v}$ ] y cuarenta leguas se cuentan a penas setenta pequeñas poblaciones compuestas en la mayor parte de ranchos de pajas o bohíos miserables, y en ellas sobre [pues] más o menos la sola totalidad de setenta, y cinco mil almas, número ciertamente desproporcional, y tan corto que cualquiera sola ciudad de segundo orden lo contiene más crecido $=$ Es innegable que la multitud de habitantes esparcidos por los montes, que en ellos han fijado su domicilio, y subsistencia contribuye infinitamente a este grande vació que sufre la población porque estos individuos dispersos, vagos, y sin aplicación, de ningún modo cooperan a su fomento, ni están en aptitud de producir aquel orden ni de propagar aquellas ventajas que indubitablemente resultarían si estuviesen reunidos en poblaciones arregladas, y congregadas en sociedad: si se inspecciona la provincia por cualquiera de sus ángulos se hallará sembrada de estos hombres incultos que remontados a la [espesura] de los bosques, y alejados de toda comunicación racional se puede decir que son unos miembros perniciosos e inútiles para el estado, pues sumergidos en la ociosidad, en la estupidez, y en los crímenes más vergonzosos ignoran las máximas de nuestra santa religión, no cumplen con sus deberes, ni reconocen la corrección ni la disciplina de las leyes de modo que, reducidos a subsistir de la cacería, y robo solo se dedican (cuando mas) a la siembra de un poco de 
maíz el suficiente a penas para la composición de sus chichas con que fomentan sus frecuentes embriagueces [folio 855r] relajación, y escandalosa conducta $=$ Sera por tanto, más digno de la justicia, y de la paternal vigilancia de nuestro muy amado soberano reducir desde luego a estos hombres díscolos y a estas familias holgazanas a que agregándose a las poblaciones más inmediatas, o formando otras de nuevo en aquellos pasajes en que puedan ser convenientes se constituyan así útiles a la religión, y al estado, sustrayendo los del genero de vida feroz, y montaras en que hasta ahora se han mantenido, por cuyo medio mejoradas sus costumbres se acrecentara la población; y la agricultura recobrara estos brazos para la labor de las muchas tierras cultivables, que abandonadas por falta de operarios influye en la grande carestía de frutos, y de granos que casi siempre se experimenta $=$ tan persuadido ha estado siempre este cabildo de la necesidad de semejante providencia que en representación que dirigió a su majestad en diecisiete de agosto de mil setecientos ochenta, y siete impetrando de su real piedad varias gracias para alivio, y fomento de esta provincia, le propuso, y pido entre ellas el establecimiento da los márgenes del Rio Chagres de dos, tres, o más poblaciones situándolas, en los puntos, y parajes más ventajosos, y formándolas de estos hombres vagos, sin aplicación, que viven dispersos por las montañas, y campos [folio 855v] y su majestad por su real orden expedida en Aranjuez a veintiuno de junio de mil setecientos noventa, y cuatro, y comunicada al excelentísimo señor virrey, quien la transcribió a este gobierno, se dignó a probar el pensamiento mandado se verificasen por medio de pobladores particulares con arreglo a los dispuesto por las leyes de indias, lo cual no obstante, ignora este ayuntamiento porque hasta ahora no habrá tenido efecto esta soberana disposición cuando son tan manifiestas, y demostrables las conveniencias que debe producir, aumentando la agricultura en las fértiles, y frondosas vegas de aquel rio que tan a la mano tiene un puerto de exportación por el lado del norte, al mismo tiempo que estos colonos arrancados de sus montaraces guaridas, y reducidos a vivir en sociedad, proporcionarían a los pasajeros comodidad, y auxilio en sus nuevas poblaciones y serian allí [utilísimos] para facilitar la navegación, y el transporte de las mercaderías que se internan por aquel cause, y lo que es más serian otros tantos defensores; prácticos, y prontos para en caso de guerra defender el país si fuese acometido por aquella entrada = Bajo cualquiera consideración que se premedite el asunto, opinara siempre este cabildo no debe diferirse la reducción forzada o poblado de estas gentes dispersas, pues no solo en la comprensión de esta capital si no en todos los distritos de la provincia están excesivo su número que si se tolerase por más tiempo se irían quedando los pueblos sin vecindario y la insubordinación, y perversidad de costumbres [folio 856r] se constituirían incorregibles; pero es indispensable para remediar un mal que ha llegado a ser ya tan grave que las providencias sean vigorosas y generales; vigorosas para que por ningún pretexto se eludan; y generales, para que a este mismo tiempo en todos los partidos se pongan en ejecución a fin de que estos hombres siendo extraídos de un distrito a montaña no tengan la facilidad de irse a establecer a otra $=$ Es cuando sobre el particular pueda exponer a usía el cabildo de esta ciudad en su sala capitular 
de Panamá seis de noviembre de mil ochocientos cuatro $=$ Ambrosio de Anzoátegui $=$ Manuel de la Barrera $=$ Antonio Jiménez $=$ Manuel José Ortiz $=$ Juan Andrés de Gaviria $=$ Doctor Miguel Bermúdez $=$ Vicente García = Juan de Dios de Icaza $=$ Francisco José de $[$ Argote $]=$ Miguel de Quesada $=$ Francisco Javier Patino escribano de su majestad público, y de provincia $=$ Panamá Noviembre siete de mil ochocientos cuatro $=$

\section{Decreto}

Por recibido aguárdense las diligencias que debe estar practicando de orden de este gobierno el alcalde mayor de Natá a quien se recordara nuevamente su cumplimiento con inserción de este decreto $=$ Doctor Cabrejo $=$ Ciriaco Hipólito Correoso $=$ Se remitió al alcalde mayor de Natá copia del decreto de arriba [fecha] ut supra = Hay una rúbrica [folio 856v]

\section{Oficio}

Impuesto del testimonio que con oficio de diecinueve del próximo pasado me han pasado vuestra merced referente a las providencias que se han tomado para que el cabildo de la Villa de los Santos [evacúese] el informe que se le pidió con fecha veintitrés de septiembre de mil ochocientos y dos, el que no ha verificado sin embargo de habérsele interpelado eficazmente, he adoptado yo los medios que he considerado más oportunos para que tenga si debido cumplimiento lo resuelto por este gobierno, y pienso remitir el informe a vuelta de correo $=$ Dios guarde a usted muchos años $=[$ Penonomé $] \mathrm{y}$ noviembre tres de mil ochocientos y cuatro $=$ Víctor de la Guardia $=$ Señor escribano mayor de gobierno y guerra de la ciudad de Panamá =

\section{Decreto}

Panamá noviembre diecinueve de mil ochocientos cuatro $=$ por recibido agrégueme a los autos $=$ hay una rúbrica $=$ Correoso $=$

\section{Real Cedula}

El rey $=$ Regente, y oidores de mi Real Audiencia de la ciudad de Santafé. Por Don Josef María [Lozano] y Peralta vecino de esta ciudad se me ha hecho presente que este reino es el menor y más preciso de la América siendo hasta a hora un esqueleto de población por los interminables terrenos, y dispersión de sus habitantes, los cuales en la menor parte son hombres del monte, díscolos e indisciplinados que, a excepción de esa capital y el puerto de Cartagena, todo lo demás ni se puede llamar población ni sacar las ventajas de la sociedad pues la Ciudad de Tunja este medio arruinada: [ folio 857r] Mompox, y Honda son Villas, pero informes: Pamplona, y Neiva Ciudades por honor: las de Alta gracia, [Anserma] ,la palma, Muso, [Tocaima], y otras han llegado a un exterminio de forma que el resto de aquellas tierras fértiles hermosas, y ricas son pueblos de indios, y parroquias, que, es decir, una 
iglesia, y una casa del cura en el centro de las campiñas, solas y sin cultivo lastimándose el corazón al ver que aquellos fertilísimos objetos, con que ha enriquecido la naturaleza, aquel país sean sus habitadores tan rustico, y montañeses. que la religión esta lastimosamente perdida y olvidada pues una cura párroco, y la justicia por celosos y visitantes que sean no pueden separados ni unidos hacer cumplir los preceptos de Dios ni de la iglesia, porque los feligreses remontados en la esperanza de los bosques alejados en la esperanza de los bosques alejados en enormes distancias, y pobres voluntarios por la ociosidad de una vida silvestre hacen vanas todas las diligencias de un pastor, y de un juez, oyendo misa los más cercanos en los días de precepto, los demás pasados muchos años habiendo gentes que nunca la han oído ni tienen idea de los templos, ni se han sagradas ceremonias viéndose bautizar muchos veces a fuerza del celo parroquial muchos de ocho, diez, y hasta de doce años hallándose también tan relajado el precepto pascual, que se ahuyentan a los [folio 857v] montes para eludir la obligación. Y propone para remedio de estos males aumento del estado, y de Mi Real Erario, el que se recogen, y unan a poblado aquellos habitantes, conduciéndoles a ser hombres por la mutua humanidad, y trato que es la [vara] para el feliz logro de tan necesarios establecimientos expidiéndose las ordenes correspondientes para que, con la posible brevedad, y exactitud se arreglen los poblados comisionando sujetos de integridad de los que se hallen asalariados por mí para obviar derechos de comisión que podrán ser los gobernadores en las provincias, los corregidores en los partidos, los oidores en las cercanías de esa ciudad y otros vecinos de inteligencia, y de interese para conducir con acierto las más proporcionadas poblaciones instando a los vecinos del respectivo territorio a que hagan sus moradas en el terreno de las parroquias, habiéndose garantes de las utilidades que reportaran, y mayormente la de huir de las vejaciones que los particulares les hacen por estar las justicias remotas no habiéndose propuesto en este pensamiento [mas] objeto que el de la felicidad de ese reino, y las riquezas considerables, que lograra el estado ofreciendo suministrar las luces que conduzcan al logro de la empresa si se le considera capaz por el conocimiento que le asiste de algunas provincias de él. Visto en mi concejo de las indias con lo expuesto por su contaduría [folio 857r-bis] general, y mi fiscal, y habiéndose consultado sobre ello en doce de febrero último ha resuelto me informéis con justificación a la mayor brevedad como os lo mando cuando se ofrezca, y parezca en el referido asunto. Fecha en Aranjuez a veinticuatro de abril de mil ochocientos y uno $=$ Yo el rey $=$ Por mandado del rey nuestro señor $=$ Silvestre Collar hay tres rubricas $=$ En la ciudad de Santafé a veintiuno de abril de mil ochocientos dos. Estando en el real acuerdo de justicia los señores virrey, presidente, regente, y oidores de la Audiencia, y cancillería real de este nuevo Reino de Granada [de] habiendo visto la Real Cedula antecedente dijeron: que la obedecían, y obedecieron en la forma acostumbrada, y que para su cumplimiento sacándose copia de este original que se archivara se de vista al señor fiscal, y los rubricaron por ante mí de que certifico = hay dos rubricas $=$ Doctor Aguilar $=$ Es copia de la original Santafé mayo cuatro de mil ochocientos dos Doctor Francisco Josef de Aguilar = Muy poderoso señor = 
El fiscal de lo civil dice: que obedecida la antecedente Real Cedula fecha en Aranjuez a veinte y cuatro de abril del año próximo pasado que igual se ha comunicado el superior gobierno donde se tiene pedido lo conveniente para su cumplimiento es demandarse guardar, cumplir y ejecutar en todo lo que previene, y para [folio 857v.bis] el efecto de instruir el informe del tribunal con la debida justificación, oír previamente los de los cabildos, y curas en la parte que a cada uno corresponde por medio de los gobernadores, y corregidores de las provincias a quienes se servirá vuestra alteza comunicar las ordenes necesarias, reservando para practicar en su vista las demás diligencias que esta superioridad tenga a bien; y que de consideren convenientes Santafé mayo siete de mil ochocientos dos $=$ Blaya $=$ Autos $=$ hay una rúbrica $=$ Proveyese por los señores virrey, presidente, regente, $\mathrm{y}$ oidores de la Audiencia, y Cancillería Real del Reino en Santa fe a diez de mayo de ochocientos dos = Doctor Aguilar = Vistos: como parece al señor fiscal $=$ Hay dos rubricas $=$ Proveyese por los señores virrey, presidente, regentes, y oidores de la Audiencia y Cancillería Real del reino, en Santafé a veintiséis de mayo de mil ochocientos dos $=$ Doctor Aguilar $=$ en Santafé a veinte y ocho de los mismos. Yo el escribano receptor pase noticia del superior auto que antecede al señor Don Manuel Mariano Blaya fiscal de su majestad quedo impuesto su señoría, rubrica doy fe $=$ hay una rúbrica $=$ Herrera es copia de su original Santafé julio catorce de mil ochocientos y dos años $=$ Doctor Francisco Josef de Aguilar = Panamá, y agosto treinta y uno de mil ochocientos dos $=$ por recibido el [folio $858 r$ ] testimonio de la Real Cédula que comprende, se obedece, cumpla y ejecute, como en ella se manda y para que se verifique. Dese vista al abogado fiscal == Antonio de Narváez y la Torre $==$ doctor don Joaquín Cabrejo $==$ Ciriaco Hipólito Correoso $==$ señor gobernador y capitán general== el abogado fiscal dice: que para cumplir con el informe preceptuado por el superior tribunal de la Real Audiencia del distrito a consecuencia de lo que su majestad ordena en la Real Cédula comprendida en el testimonio antecedente le parece sería necesario pasar una visita general y exacta de todos los pueblos de esta provincia para instruirse con práctico conocimiento del estado de su población, ocupaciones de sus vecinos, y proporciones que haya para la agricultura e industria: pero [supuesto] que esta no se verifique podrá usía mandar a los respectivos cabildos de esta ciudad, la de Natá y Villa de los Santos, que destinen sujetos de su satisfacción que verifiquen en los pueblos de la respectiva comprensión de cada uno, el prolijo y exacto reconocimiento que queda insinuado y hecho remitir las diligencias con el correspondiente informe a este gobierno, para evacuar el que manda su alteza. Panamá y septiembre trece de mil ochocientos dos $==$ Doctor Macías $==$ vistos y considerando que los cabildos por lo general están impuestos del estado en que se hallan los lugares de su [folio 858v.] distrito el de la ciudad de Natá y el de la Villa de los Santos informen sobre el contenido de esta Real Cédula y para cuyo efecto se expedirá orden y se les remitirá copia de ella, y si acaso de alguno o de algunos de ellos no tuvieren el conocimiento necesario destinaran sujeto de su satisfacción, que hallándose instruido de lo referido les ministre las luces necesarias para dicho efecto $==$ Narváez $==$ doctor Cabrejo $==$ proveyó $\mathrm{y}$ 
firmó este decreto el señor don Antonio de Narváez y la Torre, Brigadier de infantería de los Reales ejércitos, gobernador capitán general y subdelegado general de Rentas Reales de este reino con dictamen del señor doctor don Joaquín Cabrejo, su teniente asesor general quien también lo firmó == Panamá y septiembre veintitrés de mil ochocientos dos años $==$ Ciriaco Hipólito Correoso $==$ Respecto al atraso que se experimenta en el informe que se ha pedido a los cabildos de Natá y Villa de los Santos recuérdeseles por la escribanía de este gobierno con copia de este decreto y el de veintitrés de septiembre del año próximo pasado a fin de que se le evacuen y remitan a este gobierno con la prontitud posible para que no se demore el curso de este expediente $==$ doctor Cabrejo $==$ Proveyó y firmó este decreto el señor doctor don Joaquín [folio 859r.] Cabrejo, abogado de los Reales Consejos, teniente de gobernador, auditor de guerra, asesor general de gobierno que despacha lo político por enfermedad del señor gobernador y comandante general de este reino. Panamá y enero veintiséis de mil ochocientos y tres años $==$ Ciriaco Hipólito Correoso == vuélvase a recordar a los Cabildos de la ciudad de Natá y Villa de los Santos el pronto despacho del informe que se les ha pedido con arreglo a la Real Cédula y decretos de este expediente remitiéndoseles nuevamente testimonios de ellos y se espera que lo verifiquen con la prontitud posible con apercibimiento que en su defecto será del cargo de los culpados y negligentes los resultos y perjuicios que ocasione la demora y se tomarán las demás providencias que convengan para que se haga efectivo su cumplimiento. $==$ Urbina $==$ doctor Cabrejo $==$ Proveyó y firmó este decreto el señor don Juan de Urbina, brigadier de infantería de los reales ejércitos, gobernador y comandante general y subdelegado general de Rentas Reales de este reino; con dictamen del señor doctor don Joaquín Cabrejo su teniente asesor general quien también lo firmó. Panamá y agosto veintidós de mil ochocientos [folio 859v.] cuatro años $==$ Ciriaco Hipólito Correoso == concuerda con la Real Cédula y diligencias de que hace mención que quedan en el expediente de la materia en la oficina de gobierno de mi cargo a que me remito. Panamá agosto veintitrés de mil ochocientos y cuatro años $==$ Ciriaco Hipólito Correoso == Villa de los Santos, sala de Ayuntamiento y octubre seis de mil ochocientos cuatro $==$ por recibida con el oficio que se acompaña se obedece en la forma ordinaria, cúmplase, guárdese y ejecútese como en ella se previene y para el mayor acierto désele vista al procurador general de este pueblo y con lo que expusiere tráigase a la vista y tómese razón en el libro que corresponde. Proveímos y firmamos el decreto anterior en nuestra sala de ayuntamiento. Fecha ut supra $==$ Villarreal $==$ Cuervo $==$ Villalaz $==$ Ríos $==[$ Izarbe $]==$ señor Cabildo Justicia y Regimiento $==$ el procurador general a la vista que usía se ha servido darle de la [-------] Real Cédula de su majestad (Qué Dios guarde). Fecha en Aranjuez a veinticuatro de abril de mil ochocientos uno que motivó el celo de don Josef María Lozano y Peralta, vecino de la ciudad de Santa Fe por el amor patrio en que manifiesta primeramente a su majestad ser un reino es espacioso [folio 860r.] y precioso [ilegible por tinta corrida] de que no duda el presente ministro la verdad de este informe pues por el ve a las claras que en igual época se halla esta villa en sí y sus comarcanos pueblos prometiendo por los dotes que le adornó el 
autor de la naturaleza la mayor felicidad a sus habitantes de cuyos dones no gozan por los mismos motivos representados por el dicho don Josef María respecto de aquel y se experimentan en este siendo la causa motiva de la desolación que de día en día se va experimentando tanto de habitantes como de haciendas y caudales los que con mucha dificultad haré de manifiesto.==

$1^{\mathrm{a}}$

Es innegable que el año de mil setecientos sesenta era esta villa el más penoso lugar de todo este reino, habitaba de muchas e ilustres familias con conocidos caudales y cuantiosas haciendas tanto de ganados, bestias y demás, cuanto de trapiches, huertos y tejares, sin que por la atención de estas faltaren hombres para la agricultura de los demás granos que se dan en este país en demasiada copia: acredite esta verdad la capital de Panamá; pues en ella con dificultad se hallará una casa que sus fragmentos de madera, teja y ladrillo no hayan sido conducidos de esta villa: digo igualmente el mayor abasto de comestibles ¿de donde [folio 860v.] se le ha suministrado, sino de estos puertos? Y no solamente esa ciudad sino aun todos los pueblos del reino expongan si en esos tiempos las embarcaciones que navegaban a estos puertos no eran todos barcos grandes y propios de estos vecinos y aun no daban abasto a la conducción de las cargas que había que transportar; y hoy seis u ocho canoas aun con dificultad y espacio de tiempo consiguen cargar ¿pues qué motivos tan ruinosos han podido en tan pocos años destruir esta y sus pueblos adyacentes hasta ponerla en el infeliz estado en que la vemos?

El primero han sido los estancos de tabacos y aguardientes pues antes comerciaban estos vecinos con ventajosas utilidades en uno y otro ramo; bien que a sus principios no fueron de tanto estrago; por que la renta de tabaco era en rama y la de aguardientes por la cantidad que cada cual quería: de forma que comprando de uno y otro tenían utilidad en la labor del tabaco y en el menudeo de los aguardientes, y de esta manera honrosamente se mantenían muchas viudas con sus hijos, muchos casados con sus familias y otros tantos se sostenían y mantenían sus obligaciones con el salario que ganaban en labrar cigarros a los que tenían este comercio. El público [folio 861r.] estaba bien abastecido, pues cada cual para lograr mejor venta se esmeraba en la buena labor, porte y aumento de número de cigarros por medio y en los aguardientes la mejor medida y mayor aseo. El corto lucro que les prometía esta tarea cesó prontamente con labrar de cuenta de su majestad los cigarros, y menudear en los estancos los aguardientes y no solamente faltó sino que originó este mayor perjuicio cuando se publicó por bando la labor del tabaco por cuenta de la Real Renta se ofreció a nombre de su majestad dar ocho cigarros por medio de buen porte y calidad. Remito a la prudente [juiciosidad] el perjuicio por tantos modos, que en esta determinación se ocasionó a todo el reino y que la Real palabra del soberano no puede faltar a su cumplimiento y que si mal informado asintió esta labor sin hacerle presente quien tal le informó los 
innumerables daños que haría en lo espiritual y temporal a todos sus habitantes y que la piedad católica de su majestad no puede asentir por bien del aumento de su Real erario en perjuicio de sus vasallos. Pero vamos a lo ofrecido ¿se ha verificado en esta villa ni en lo demás de la [folio 861v.] jurisdicción los ocho cigarros ofrecidos y de la manera que se ofrecieron? No pues desde el principio dieron y dan siete cigarros por medio y estos las más veces malos, pasados, rotos y aun podridos en tal grado que ha llegado el caso de privar su uso los médicos por nocivos a la salud.

\section{$3^{\mathrm{a}}$}

Es muy digno de reparo al presente ministro esta falta a lo propuesto ¿podrá persuadirse de alguna manera que directa o indirectamente tiene en esto prenda Su Soberano? Nada de eso: antes por el contrario, como que ve lo mal que asiente de este perjudicial procedimiento contra sus vasallos e hijos por quienes tan piadosamente siempre ha visto y procurado derramar copiosas gracias a efecto de que logren la mejor subsistencia en su salud, vida y haciendas y que por este conocimiento lo amen como a padre, lo sirvan como a señor y lo veneran como a su soberano; en vista de lo expuesto ¿cómo habrá de persuadirse que su real piedad consienta que se hostilice a sus vasallos, no solamente en más de sus catorce por ciento qué con cercenarles el un cigarro en cada medio son pensionados, sino la calidad y circunstancias expuestas de dichos cigarros? Añádase a esto que en los tiempos del verano [folio 862r.] por razón de los vientos nortes no pueden navegar las canoas y falta el tabaco en la administración, y les es forzoso comprarlos a los que para lucrar o para su gasto lo traen de la de Panamá a cuatro cigarros por medio, y ha llegado el caso que hasta a dos, durando esta escases algún tiempo sucediendo igual caso en los aguardientes de forma que ha motivado a la infidelidad de usar de una y otra especie clandestinos sin que por los jueces y administradores se les haya podido corregir o castigar esta tan notable falta; motivos sumamente ruinosos y perjudiciales por tantas causas a la república.

Pasemos a otro punto de mayor consideración en lo perjudicial y total desolación de los vecinos, caudales y haciendas de esta villa y su partido. El primero de junio de mil setecientos setenta y tres se arreglaron las milicias disciplinarias en esta dicha villa y sus respectivos pueblos componiéndola de nueve compañías: fue digno de elogio el gusto y complacencia con que voluntariamente se presentaron tantos jóvenes de dieciséis a veinte años a porfía sobre cual se había de alistar primero, temiendo de quedar sin el logro de ser comprendidos en el arreglo, como les sucedió pues habiéndose escogido por el jefe los que fueron necesarios de la mejor color, talla y quedó sobrante mayor número que el elegido con sumo sentimiento de ellos y todo este acopio de solteros y de los que sin perjuicio podían y debían servir [folio 862v.] a su majestad. ¿Quién duda lo benévolo que se juzgaron los de este país si les era el arreglo de esta milicia por el provento que se pensó tener en 
el monto de sueldos de los veteranos empleados por la mejor venta de comestibles y demás de sus comercios en la perpetuidad de un sargento mayor con cien pesos; un ayudante menor con cincuenta; nueve tenientes con treinta y seis; nueve sargentos con dieciocho; los cabos con catorce; pífanos y tambores con doce, cuyo dinero había de circular mensualmente para la manutención y subsistencia? ¿Cómo no se prometerían el más ventajoso éxito? Pero hagamos examen de él. ¿Subsistió este premiado o prometido beneficio? No: que el año de setenta y nueve en que se publicó la guerra, comenzaron a hacer sacar de gente para la capital y despacharlos a los destacamentos y esto con tanta repetición que habiendo durado la guerra cinco años, antes de los dos ya habían despachado más de mil hombres, tanto por la ocurrencia como por los muchos que morían y era forzosa su reposición. Visto esto por estas gentes y que de tantos que iban no había ninguno, comenzaron a resistirse y a huir de forma que era menester salir con guardias a cogerlos haciéndoles costos y apremiando a los padres, madres y mujeres con castigos a la entrega de los que no encontraban, y a más de lo dicho, en los tres restantes años conociendo el sargento mayor el terror que [folio 863r.] les causaba la ida al servicio; si el comandante general pedía (supongo) cien hombres, para mandarlos, (si acaso se verificaba), cogía trescientos o cuatrocientos para que cada cual por sí o por sus padres le fueran contribuyendo con lo que a su antojo le pedía a cada uno, para librarse de la marcha, bien satisfecho de que solo tenía que enviar cien hombres, y así con los restantes que cogía de más, era el lucro, lo que para verificarlo les era forzoso quemar de sus bienes lo mejor por menos de su valor. Y aun ese mismo que hoy se rescataba, como estaba satisfecho de no ir al servicio, no había y así era nombrado en la venidera, para lograr el sargento mayor el mismo injusto cohecho, de forma que hubo hombre que fue tercera y cuarta vez rescatado, hasta que ya no teniendo con que contribuir siempre marchaba. Los que no tenían para la contribución de lo que les pedía iban, sin que les valiese ser hijos únicos de viuda, de padres sexagenarios, casados con hijos menores, sustentadores de sus hermanas doncellas, huérfanas, ni asilo alguno; cuya tiranía en los cinco años de esa primera guerra por el menor número no dejaron de faltarle a esta villa y su partido más de tres mil hombres de la mejor flor, benéficos a la república, por ser todos labradores y por consecuencia muchas mujeres que con sus hijos se fueron en busca de sus maridos; y a más muchos padres de familia que con toda ella se despatriaron a la provincia [folio 863v.] de Santiago de Veragua. Otros desde ese tiempo se han acogido a lo inculto de las montañas, donde viven con toda carencia así espiritual, como razonable, habiéndose asolado este territorio no solo de estos habitantes sino también de la ruina de casas, huertos, trapiches, tejares y haciendas de ganados no tan solamente de los conducidos al servicio y de los forajidos por la destrucción que hacían ellos y sus padres para cohechar al sargento mayor, sino los que de otros particulares cuidaban que con su ida, y el terror de los que había de no manifestarse también se arruinaron y muchas del todo fenecieron. 
Concluida esta guerra el año de ochenta y cuatro a su principio soltaron las milicias: ¿y cuánto número se reintegraría del dicho que se había despatriado? No llegaron por cierto a cuatrocientos y estos los más inválidos y los restantes lejos de ser útiles a la república eran en sumo grado perjudiciales, porque ya no les acomodaba el trabajo del país y solo estaban encenegados en todos vicios, por lo que a su ejemplar se pervertían otros.

Duró este descanso hasta fin del mismo año en que se emprendió la conquista de los indios y se pusieron los establecimientos de Sabonia, Carolina [--] que duró hasta el año de noventa en los establecimientos se guarnecían con la mayor parte de esta milicia. Imponderable es el [folio 864r.] número de hombres, que en los seis años de su duración murieron en ellos e indecibles las atrocidades con que se manejó el sargento Mayor don Josef Suárez, tanto en lo personal como en lo pecuniario con esta miserable gente; y solo queda dicho con asentar que fue un activo fuego que abrasó y consumió todo este partido, dejándolo en el lamentable estado en que se ve, cuyo público comprobante se podrá hacer aun con los mismos oficiales, sargentos, cabos y tambores veteranos que de su tiempo subsisten.

\section{$7^{\mathrm{a}}$}

Cuán lejos se ha experimentado de lo que se prometieron en todo y por todo, pues se ha visto la total destrucción de la pérdida entre hombres y mujeres y niños de más de seis u ocho mil almas y sus descendencias la de sus haciendas, deterioros y ruinas de las de los demás vecinos que por falta de quienes la cuiden se han perdido o menoscabado, ha faltado la circulación de los sueldos de los oficiales veteranos con la extinción de los tenientes y reducción de solo el sargento mayor y tres ayudantes mayores de los cuales ninguno habita en esta villa sino en Panamá; excepto un ayudante mayor que vive en Parita, en los que se ha notado mucha rectitud y desinterés en todos los asuntos, tanto los que pertenecen al servicio real como en los peculiares de cada uno, y solo han quedado en esta villa algunos sargentos, tambores [folio 864v.] y cabos para la instrucción de estas compañías estando los demás en sus respectivos pueblos.

\section{$8^{\mathrm{a}}$}

También ha coadyuvado al deterioro de los que pudieran devolverse a su país los muchos hombres que de dichas milicias han cogido para el batallón fijo de Panamá de que se compone el mayor número de dicho batallón. No es de menos consideración el ver los motivos que pretextan para huir (además de los dichos) de la frecuencia y ocurrencia a los templos para el uso de los santos sacramentos y demás piadosas obras, la ninguna claridad que reciben de sus 
ministros pues han experimentado en muchos de ellos que al padre de familias que supongo casado con copia de hijos, muriéndose uno ocurre al afligido padre a solicitar su entierro donde su párroco, y este le toma especulativa residencia aun hasta de los cortos bienes que tiene para que los venda para pago de dicho entierro sin reparar en la mujer e hijos que no le queda para la mantención de ellos el siguiente día; y aun no encontrándole bienes algunos, sin reparo de su familia le obliga a que con su trabajo personal satisfaga los derechos con pretexto de que de todos ellos les compele y apremia el ilustrísimo señor obispo a que le contribuyan con la cuarta parte, cuya institución o causas con que dicho señor ilustrísimo los pide y recibe ignora el presente ministro, y juzga le [folio $865 r$.] ignoran todos pues al ilustrísimo señor doctor don Remigio de la Santa y Ortega cuando vino a este obispado le hizo novedad este derecho; y dijo públicamente que ignoraba la causa de él no usada en la Europa sucediendo lo mismo con los casamientos y demás; por cuya causa y ser para la miseria del país crecidos derechos hay tantos concubinatos y demás desórdenes en este punto lastimeros por todos modos.

$9^{a}$

Estos son los principales puntos que comprende este ministro más ruinosos que han motivado a la destrucción general de este partido y que sin el oportuno remedio de ellos en muy pocos años será de un todo exterminado, cuyo conocimiento y el que el amor y piedad de nuestro católico monarca manifiesta en su benigna real orden que desea saber el quebranto de este reino para su reparo; le parece al exponente ministro que usía a vos y nombre de su partido (como él lo hace se sirva en el informe que se le pide y debe dar suplicar a su majestad) que los estancos queden en su primer ser vendiéndose el tabaco en rama y por sus primeros precios. Los aguardientes por lo que cada cual quiera comprar e igualmente los precios y medidas primarias. La milicia que sea estable en su domicilio según se creó. Que su sargento mayor y ayudante vivan existentes en su cuerpo, esto es en el centro de su regimiento que es esta villa y lo mismo los demás veteranos, que para [el sustento] de la justicia y mejor disciplina [folio 865v.] militar haya siempre en esta villa como capital del partido una compañía al sueldo alternativamente de medio a medio año. Que no pueda esta dicha milicia sino en caso muy extremo salir fuera de su territorio. Que se cumpla con lo mandado por su majestad en hacer en cada lugar un campo santo para sepultar los cadáveres con cuyo motivo se rebajarán los derechos eclesiásticos. Que se extinga el de las cuartas episcopales. Que el papel sellado vuelva a su primer valor, con cuya benigna gracia conseguirá su majestad el ingreso de todos a sus respectivos pueblos; el mejor fomento de ellos y por consecuencia aumento en su real erario por la mejor inversión de sus habitantes tanto en lo espiritual como en lo temporal sustento la justicia y amoroso y sumiso reconocimiento en sus vasallos. Es lo que considera (para obrar más difusión en esta vista) este ministro recordar a vuestra señoría para que lo haga a la pía magnanimidad del soberano sin que se le note por arrojo lo que hace de manifiesto; pues lo ejecuta en fuerza de la verdad, y [cargo] del ministerio; sobre que vuestra señoría determinará lo que 
estime por conveniente, Villa de los Santos y octubre dieciocho de mil ochocientos cuatro años == Josef de Izarbe == señor gobernador y capitán general == El Cabildo Justicia y Regimiento de la Villa [folio 866r.] de los Santos, y su jurisdicción cumpliendo con lo mandado por usía relativo a la Real Orden expedida en Aranjuez a veinticuatro de abril del año próximo pasado de mil ochocientos uno que la motivó la representación hecha a su majestad (que Dios guarde) por don Josef María Lozano y Peralta vecino de la ciudad de Santa Fe la misma que en testimonio ha dirigido a usía a este gobierno incorporadas las providencias relativas que obró el supremo Consejo de Indias, Real Audiencia que reside en dicha ciudad, y lo que en su vista se ha mandado por usía con audiencia del ministro fiscal que todo lo tiene este cuerpo a la vista, y tuvo por necesario el comunicarla al procurador general de este ayuntamiento con el objeto de que instruido en cumplimiento de su ministerio, expusiese cuanto estimase útil al espíritu de la Real Cédula y bien de los vasallos de cuyo modo pudiese este Cabildo sobre los más prudentes principios formar el informe que vuestra señoría le tiene mandado dar: haciendo aquel ministro expuesto cuanto aparece de la anterior vista sobre que ha formado este cuerpo el más escrupuloso examen y ha oído a los varones más antiguos por hallarse desnudo de documentos que nos aseguren los verdaderos principios de los lastimosos detrimentos que adolece en general todo en nuevo reino de Granada, y conciliando tiempos y circunstancias descubre este tribunal que la miseria lamentable del reino [folio 866v.] incuestionablemente tuvo su principio en las que detallan los capítulos siguientes $==$ Sea el primero que desde la época en que se trasladó el comercio del Perú por el Cabo de Hornos cesó en el reino y principalmente en este Istmo aquella fertilidad y riqueza que le prometía el pingue comercio, cuya copiosa utilidad se difundía hasta el más humilde siervo, por este urgente motivo se atenuaron las venidas de embarcaciones al puerto de Panamá, cesó la introducción de los víveres que con abundancia se nos conducían tomaron aumentos los costos que se nos conducen en los precios a que los conseguimos y que quedaron los nuestros de la tierra sujetos a venderse a unos precios íntimos y por incidencia perdieron estos hermosos países su hermosura quedando hechos esqueletos de calamidades y miserias. El segundo motivo y coherente al primero concibe este Cabildo es haber su majestad suprimido y apartado de esa ciudad el solio de la Real Audiencia pectoral que en ella residía por esta circunstancia cesó a este Istmo el que se distribuyese y circulase entre sus naturales y europeos los sueldos que los ministros que la componían gozaban cuyo beneficio se extendía hasta el pueblo más remoto y de uno y otro innegable principio es procedente las faltas de esquelas y relativa a esta la escasísima instrucción y conocimiento de los rudimentos cristianos y sagradas [folio 867r.] ceremonias de los divinos oficios sobre cuyos puntos el procurador general tiene exclamado en su vista el tibio o remoto fervor al culto de Dios, tal vez ocasionado de la necesidad y desnudez más que de la voluntad pues es práctico que aquellas miserias y los delitos a los más timoratos ciudadanos los obligan a retirarse a los bosques a vivir vida brutal los que hicieron hombres racionales. Tercero: no encuentra este Cabildo menos gravoso el proyecto de que esa plaza y las demás del reino 
sean guarnecidas de naturales de estos dominios y no de europeos como anteriormente este advirtió embebe en sí para la subsistencia de estos países dos perjuicios, primero que siendo guarnecidas por los criollos o naturales como hombres todos de trabajo hacen eminente falta al cultivo de las tierras y en las ocasiones que puedan ofrecerse miran las armas expuestas, por no ser estos naturales del espíritu bélico, que los europeos; el segundo que estos difunden su sueldo mensual y su circulación hace en parte feliz este Istmo, y a esta utilidad que reporta se llega que muchos de los europeos se casan con las hijas del país de que resulta que en la propagación se halle nuestra sagrada religión más arraigada. Cuarto: ya habrá llegado a la sabia comprensión de vuestra señoría los estragos y lamentable miseria que han ocasionado los estancos de Aguardiente y Tabacos en todo el distrito que comprende [folio $867 v$.] su gobierno, más urgentes y eficaces desde que se proyectó que no se vendiese el tabaco en rama y si en cigarros, sobre cuyos puntos nada tiene que expresar este cabildo, para comprobarlos a vista de cuanto el procurador general sobre ello tiene expuesto como ha expuesto sobre el doble costo del papel sellado esta circunstancia, y en la distancia que se halla la Real Audiencia, se hace en extremo grado perjudicialísimo a la causa pública y a estos naturales los aterra y sujeta a que abandonen sus acciones por no poder sostener y costear su fragoso y dilatado recurso. Los capítulos precedentes juzga este Cabildo que manifiestan vuestra Señoría los motivos más recomendables que han hecho desolación de la hermosura y fertilidad con que estos países y naturales que los habitan se hacían felices y enriquecían el Real Erario, la Real benignidad cuando se interesa en averiguar el motivo del daño se expresa y recomienda que le faciliten y manifiesten los arbitrios útiles de conseguir su reparación y bien, a este propósito haya este cabildo indubitable y eficaz remedio que su real soberanía por un efecto de la plena potestad Real y paternal amor se digne reponer el comercio del reino del Perú como anterior, por Portobelo y Panamá, que estas plazas se guarnezcan de tropas europeas [folio 868r.] que la Real Audiencias se restituya a la ciudad de Panamá, o que su Real Magnificencia (como puede) erija y establezca en dicha ciudad este tribunal; que los estancos de tabacos y aguardientes queden suprimidos a vender en rama y por mayor en las dos administraciones principales; que la labranza de cigarros y menudeo del aguardiente queden como en el tiempo de sus establecimientos por arbitrios y beneficios de los vasallos sin que a tan benigna y justa solicitud obste el escollo que pueda oponerse de las clandestinidades porque este arbitrio es más efecto de la miseria que de la infidelidad y una y otra queda puesta a salvo con que la ronda que goza sus respectivos sueldos incesantemente circule el istmo cele y embarace todo fraude: que su majestad de cuenta de un Real Hacienda o por la de particulares facilite la introducción de negros para sostener los trabajos que se emprendan; que se interese su Real Autoridad en prohibir que ningún individuo del cuerpo eclesiástico y militar que goce sueldo se introduzca en ningún arbitrio del comercio temporal ni profano según les está prohibido por Reales disposiciones y bulas pontificias que se establezcan escuelas de primeras letras y latinidad a lo menos en todos los pueblos de las cabeceras, que en todos por los muchos más prudentes y benignos se conduzcan los naturales 
dispersos [folio 868v.] de ellos a vivir a los poblados que mejor les acomoden de cuyo modo así los párrocos como los jueces podrán celar más oportunamente sus respectivas obligaciones y lograrse más frecuente concurrencia a los templos done podrán formar una idea cristiana de los divinos oficios y sagradas ceremonias y cumpliendo con los preceptos de Dios y de nuestra Santa Madre iglesia ponerse aptos a conseguir la mayor felicidad y estar a salvo de las vejaciones que están expuestos a sufrir de los poderosos; finalmente que su majestad católica manda de su real clemencia en los futuros casos que puedan ocurrir e guerra prohíba (como lo tiene mandado por Real Cédula) que de esta villa y su partido no se extraigan ni saquen para ninguna guarnición sus moradores así por la calamidad que ocasiona su falta como porque toda esta ensenada y costa se halla surtida de puertos donde cómodamente puede la nación inglesa, nuestras enemigas, tomar posesión y haciéndose firmes ser lo temibles y respetables y sin mayores fuerzas hacer invasión y originar los insultos que a ella fueran consiguientes; que en subsidio de urgentísima necesidad de esa plaza y otro pueblo, el socorro sea de cao de las justicias el facilitar el posible y que este sea de los hombres vagos y de estragada [folio 869r.] conducta sin distinción de calidad, condición ni estado cuyas legales y benéficas reglas incuestionablemente facilitan la reparación de los lastimosos objetos que tuvo a la vista el representante don Josef María Lozano y Peralta, y de los que cuan iguales tiene a la vista este ayuntamiento y el procurador general tiene expresados. Es cuanto puede este cabildo por sí y a nombre de todos los vivientes de su distrito y con respecto a la Real Orden informar a vuestra señoría como lo ejecuta en la sala capitular de sus acuerdos y noviembre siete de mil ochocientos cuatro. Por ante nos por no haber escribano de que certificamos $=$ Segundo de Villarreal $==$ Josef Marcelino Cuervo $==$ Antonio José Pérez == Ignacio González de Villalaz == Josef de Izarbe == Marcelino Rodríguez == incluyo a usía el conjunto expediente en que se halla el informe que hice extender al cabildo de la Villa de los Santos a consecuencia de lo que previene su majestad en Real Cédula de veinte y cuatro de abril de mil ochocientos uno y si sobre el mismo asunto tiene usía por conveniente oír lo que me ocurra por lo tocante al distrito de esta alcaldía mayor con su aviso le expondré lo que considere conveniente al fomento de estos pueblos por el conocimiento práctico que tengo de este que están a mi cargo == Dios guarde a usía muchos años, Penonomé y noviembre trece de mil ochocientos [folio $869 v$. ] cuatro $==$ Víctor de la Guardia $==$ señor gobernador y capitán general de la ciudad de Panamá == Panamá noviembre diecinueve de mil ochocientos cuatro $==$ pase al señor asesor general $==$ Urbina $==$ Panamá diciembre siete de mil ochocientos cuatro $==$ por recibida con el informe del cabildo de la Villa de los Santos vista al abogado fiscal == hay dos rúbricas == Correoso $==$ señor gobernador y capitán general == el abogado fiscal en vista de los informes de los cabildos de esta ciudad, la de Natá y Villa de los Santos dice: que todos concuerdan en la de población general de esta provincia y su mísera constitución que atribuyen a las varias causas que exponen en sus respectivos informes bien que conviniendo en el retiro a los montes de muchos de sus moradores y a la poca o ninguna aplicación al trabajo que en ellos se advierte 
dedicados a una vida ociosa y vagabunda, llena de vicios que es desde luego, en el concepto del fiscal, el motivo principal de la pobreza y decadencia de toda la provincia, pues proporcionando en ella la naturaleza muchos medios de enriquecerse y hacerse feliz no saben o no quieren aprovecharlos por no fatigarse con el trabajo de que proviene que aunque muchos vecinos honrados quieran dedicarse o se dediquen a beneficiar la tierra, sus minas sacando de ellas y de los mares y montes las preciosidades [folio $870 \mathrm{r}$.] y tesoros de que abundan, no lo pueden conseguir por falta de brazos, pues no encuentran jornaleros ni tienen suficientes esclavos que les ayuden, y aunque desde luego debe esto ponerse en consideración de la Real Audiencia pretorial del reino a consecuencia del informe que ha pedido a vuestra señoría para que todo lo eleve al soberano como su majestad lo ordena pero debe atenderse sin perjuicio de que por vuestra señoría se tomen las más activas providencias para que se reduzcan a poblado, vida cristiana y civil las gentes dispersas en las montañas según el espíritu de las leyes municipales y principalmente la primera del título 3 libro 6, cuyo cumplimiento debe ser ejecutivo sin necesidad de nueva Real orden como también el que se persigan y castiguen los ociosos y vagos que no tengan oficio ni beneficio según y con arreglo a las leyes del reino mandándose para ello formar padrones exactos de todos estos vagos así para corregirlos y darles destinos proporcionados a su clase como para que con ellos y los dispersos en los montes se procure realizar la fundación de los pueblos en los márgenes el río de Chagres que enuncia el muy ilustre cabildo de esta ciudad en cumplimiento de la Real Cédula que cita expedida en el asunto y que debe llevarse a debido efecto por los muchos beneficios que resultan de su cumplimiento == Panamá y diciembre dieciocho de mil ochocientos cuatro == otrosí dice el fiscal que puede vuestra señoría mandar que el alcalde mayor [folio 870v.] de Natá informe lo que parezca sobre el punto que se trata según lo ofrece en su antecedente oficio para que todo se dirija a la Real Audiencia a quien deben dársele todos los conocimientos conducentes a su más cabal instrucción de la materia y que así ella dirija a su majestad el informe circunstanciado que le ha pedido. Fecha ut supra. == doctor Macías == Autos == hay dos rubricas == proveyó $\mathrm{y}$ rubricó este decreto el señor don Juan de Urbina, brigadier de infantería de los Reales Ejércitos, gobernador capitán general y subdelegado general de rentas Reales de este reino con dictamen del señor doctor don Joaquín Cabrejo su teniente asesor general quien también los rubricó. Panamá y diciembre veinte de mil ochocientos cuatro años $==$ Ciriaco Hipólito Correoso $==$ en Panamá en dicho día mes y año hice saber este decreto al doctor don Rafael María abogado fiscal $==$ hay una rúbrica $==$ Correoso $==$ Panamá, enero dos de mil ochocientos cinco $==$

\section{Auto}

Vistos y sin embargo de haberse expedido varias providencias anteriormente para que se reduzcan a poblado las gentes dispersas en los campos y montes recomendando este asunto a las respectivas justicias del distrito de este gobierno; reitérese nuevamente lo referido según y cómo lo pide el abogado 
fiscal y mediante a la dilación ocurrida por [folio 871r.] haber demorado su informe el cabildo de la Villa de los Santos, para que no se experimenten mayores dilaciones hágase el informe con testimonio del expediente a la Real Audiencia del distrito como lo tiene mandado, y dese aviso al alcalde mayor de Natá para que por su parte infirme como ofrece a la mayor brevedad a fin de que se dirija sin pérdida de tiempo a aquel regio senado == Urbina == doctor Cabrejo == Ciriaco Hipólito Correoso == en Panamá en dicho día, mes y año hice saber este auto al doctor don Rafael Macías, abogado fiscal == Hay una rúbrica $==$ Correoso $==$ entre occidentales a su perniciosos [en mandado] [r] [g] [en todo vale].

Concuerda con el expediente original de que hace mención que queda en la oficina de gobierno de mi cargo, a que me remito y en virtud de lo mandado doy y firmo en presente en Panamá, enero ocho de mil ochocientos y cinco años. Ciriaco Hipólito Correoso [rubrica] [folio 871 v.]. Muy poderoso señor, Santa Fe, febrero 19 de 1805. A su expediente [borroso] Aguilar. Impuesto de la Real provisión de Vuestra Alteza lo que puedo informar concerniente a la Real Cédula 24 de abril de 1801 es que habiendo pasado aún a los cabildos de esta ciudad y a los de Natá y Villa de los Santos para que informasen con arreglo a la expresada real cédula lo han ejecutado y por lo que respecta al primero es constante que muchas de las gentes del distrito de este gobierno viven esparcidas en lo dilatado a sus montañas y aunque a fuerza del celo de este gobierno se han dado repetidas órdenes para que todos sus habitantes se conduzcan a población aunque mucha parte se ha conseguido, no ha podido lograrse en el todo por las distancias y dificultades que continuamente ocurren y algunas veces por la tibieza con que suelen manejarse las justicias foráneas y me parece que si no se comisionan sujetos de actividad y viveza con el aliciente de algún premio, no tendrán [folio 872r.] su debido cumplimiento las ordenes referidas; y por lo respectivo a las poblaciones mandadas fundar por su majestad en los márgenes del Río de Chagres, como esta deben ser bajo del pie de lo prevenido en las leyes de Indias, ínterin que no se presenten capitanes pobladores, no pueden glorificarse ni creo que se logren siempre que sean de cuenta de estos los gastos que deben invertirse para su subsistencia, sobre cuyo particular podrá la integridad de vuestra alteza arbitrar lo más útil y conveniente para su consecución, que serán allí muy útiles por ser aquel el paso de pasajeros, comerciantes y empleados para este reino y los del país. Y por lo que respecta al informe del cabildo de la Villa de los Santos, este es comprensivo de varios asuntos graves y delicados y algunos de criminalidad en general, y sin excepción de sujetos y sin más comprobantes que su [desnudicho] y si en aquellos tiempos han [obtenido] los pasajes de que trata ha faltado en no haberlos hecho presentes a los superiores para que al momento se remediasen como era justo, lo cierto es que nunca se ocurrió a mis antecesores [folio 872v.] sobre ello, pues aunque yo ha poco tiempo que me posesioné de este gobierno y no tener por esto todo aquel conocimiento que se necesita; me he informado del asesor general que hace cuarenta y un años que ejerce con integridad y desinterés este encargo y me expuso no hace memoria de que en aquel tiempo se hubiesen hecho 
presentes ninguno de los desórdenes referidos, que en tal caso se habrían tomado las providencias más serias para su castigo y corrección, pues por lo que mira a que no han disimulado los expresados gobernadores cosa alguna en esta materia, se califica con las residencias que se les han tomado a la final de su gobierno y no ha resultado cargo alguno en cuanto a esto. Y pasando a tratar sobre las causas y motivos de los atrasos y pobreza de todo este reino, en mi concepto y con grande fundamento no son otras que la falta de comercio y exportación de efectos y frutos para otras partes, lo que ha manifestado la experiencia, porque cuando en tiempo de galeones se manejaba el comercio de Lima por esta vía se reconocía este reino en su opulencia, pero desde que ha faltado ha venido al lamentable estado en que se halla y por el contrario todo [folio 873 r.] todo el lustre y brillantez de las provincias del [Guayana] y Caracas, consiste en su lícito comercio originado de los cacaos que con abundancia producen aquellos terrenos y continuamente se extraen para habana y Veracruz y España y por eso aquellos vecinos y demás comerciantes reportan muy crecidas y ventajosas ganancias, en inteligencia que si en el día les faltaran estos preciosos renglones vendrían a quedar en la misma miseria en que se halla Panamá. No se han remitido con más antelación estas diligencias por haber dilatado su informe el cabildo de la Villa de los Santos y ahora se le da curso porque o se [ilegible] mayor tardanza y al mismo tiempo se ha prevenido al acalde mayor de la ciudad de Natá que haga el informe que ha ofrecido sobre el particular, en la inteligencia que luego que se reciba en este gobierno se remitirá a vuestra alteza con 1 mayor brevedad. En esta virtud y en vista de dichas diligencias e informes podrá vuestra Alteza proveer lo que considere más útil al público y beneficio del Estado. Nuestro señor guarde a vuestra alteza los muchos y felices años que este reino necesita. Panamá, enero 10 de 1805. Muy poderoso señor Juan de Sabina [folio 873v.] 